\title{
Organizational performance in BAPAREKRAF Indonesia
}

\author{
Sutan Adil Hendra; Syamsurijal Tan; Tona Aurora Lubis*; M. Syurya Hidayat
}

Doctoral Program in Economics, Postgraduate, Universitas Jambi, Indonesia

*To whom correspondence should be addressed.Email: tonalubis@gmail.com

\begin{tabular}{|l|l|l|l|l|}
\hline DOI: & Received: & Revised: & Accepted: & Published: \\
10.22437/ppd.v8i5.11017 & 13.11 .2020 & 28.12 .2020 & 29.12 .2020 & 31.12 .2020 \\
\hline
\end{tabular}

\begin{abstract}
This study aims to analyze the factors that influence the organizational performance of BAPAREKRAF (The Ministry of Tourism and Creative Economic). BAPAREKRAF is the spearhead of a government agency for developing Indonesia's creative economy. This study's respondents are whole civil servants and civil servant candidates in BAPAREKRAF, in 194 respondents. This research shows that transformational leadership, organizational culture, managerial competence, organizational structure, and organizational trust affect organizational performance, but transactional leadership does not affect organizational performance. Besides that, transformational leadership, organizational culture, organizational structure affect organizational trust, but transactional leadership and managerial competence do not affect organizational trust. Furthermore, transformational leadership, transactional leadership, organizational culture, and organizational structure can be mediated by the trust in organizational performance. However, managerial cannot be mediated by trust in BAPAREKRAF's performance in realizing.
\end{abstract}

Keywords: Managerial competency, Organizational performance, Transformational leadership, Transactional leadership

JEL Classification: M12, M14

\section{INTRODUCTION}

The development of free trade and the global economic crisis's threat requires all countries globally, including Indonesia, to compete in domestic and international markets. A creative economy is one solution to facing this competitive competition (Junaidi, 2017; Hardiani et al., 2019). The creative economy can contribute a considerable amount to Indonesia's Gross Domestic Product (GDP). Until the end of 2018, the creative economy's contribution to the national GDP was estimated to reach Rp 1,105 trillion and again increase to Rp. 1,211 trillion in 2019. Also, the increase in the creative economy workforce has increased, namely, in 2011, there were 13.45 million people who continued to increase until it reached 16,91 million people in 2016 (BAPAREKRAF, 2018).

The Indonesian government is well aware of the creative economy's potential for the development of national welfare. As the government's response to the creative economy, the Creative Economic Agency (BEKRAF) was formed and changed to the Tourism and Creative Economic Agency (BAPAREKRAF). Given the important role of BAPAREKRAF for the national economy, it is necessary to strengthen its organization. From the perspective of human resource studies, many factors affect organizational 
performance.

One of the organizational performance is influenced by the leadership style. Arif \& Akram's research (2018) concluded that transformational leadership affects organizational performance through organizational innovation's mediating role. Toufaili (2017) adds that transformational leaders prioritize subordinates' involvement, resulting in higher efficiency and satisfaction, leading to managerial and organizational performance. Ahmad \& Ejaz (2019) added that a transformational leadership style positively influences organizational performance. Birasnav (2014) argues that leaders use values and ideologies that motivate their subordinates to specified achievement levels.

In addition to the transformational leadership style, there is also a transactional leadership style. Ahmad \& Ejaz (2019) concluded that transactional leadership has the highest impact on organizational performance, followed by transformational leadership styles. According to Haq \& Chandio (2017), in order to improve organizational performance, the transformational leadership style emphasizes the effectiveness and efficiency of employees, assesses organizational structure and structure, motivates employees by providing rewards and punishments to employees, follows strict rules and regulations, and monitors employee performance in the organization carefully

Organizational performance is inseparable from organizational culture. Sengottuvel \& Aktharsha (2016) revealed that strategic emphasis has a potential impact on organizational performance among the various organizational culture dimensions. Kim \& Chang (2018) found that clan culture and market culture were more prevalent than adhocratic cultures and that hierarchical and clan cultures would decline significantly over time. In contrast, adhocratic, clan, and market cultures have a consistently positive relationship and have the strongest impact on organizational performance. Meanwhile, Joseph \& Kibera's research (2019) found that organizational culture significantly influences non-market performance.

An organization indirectly describes its managerial competence. Suárez, Martelo, \& Franco (2018) found that managerial competence is a critical variable for achieving a healthy culture conducive to commitment quality and excellence in important educational institutions. Meanwhile, research by Ncube \& Chimucheka (2019) concluded that managerial competence affects the performance of MSMEs.

An organization must have an organizational structure. Research by Nwonu, Agbaeze, \& Obi-Anike (2017) concluded that the organizational structure of companies in manufacturing affects organizational performance. Estalaki (2017) finds a significant relationship between efficiency in industrial units and organizational structure and its components, including complexity, formality, and concentration.

Organizations need organizational trust. Organizational trust is about individuals' positive expectations from supervisors, colleagues, and the organization to be honest about promises, decisions, and behavior, and not act pragmatically. Research Guinot \& Chiva (2018) found a mediating role for trust in organizations to improve job and organizational performance. Meanwhile, Singh \& Desa (2018) examined the effect of organizational trust on job performance, and the results showed that organizational trust was positively correlated with job performance.

Thus, from some of the studies that have been described, it can be concluded that there is an influence of transformational leadership, transactional leadership, organizational culture, managerial competence, organizational structure, and organizational trust on organizational performance. Therefore, there are research gaps about organizational performance that can be researched at BAPAREKRAF.

Yue et al. (2019) show that transformational leadership and transparent communication are positively related to employee organizational trust, which positively 
affects employees' openness to change. Yasir et al. (2016) revealed a positive and significant relationship between transformational leadership and employee trust. Uslu \& Oklay (2015) demonstrated that leadership has a positive effect on organizational trust.

Yasir et al. (2016) found no significant relationship between transactional leadership and employee trust in the organization. Meanwhile, Mehmood's (2016) research in the banking sector in Pakistan shows thatTransactional leadership except management by exception (passive) dimension has a significant impact on employee trust in the organization.

Fard, Babelan, \& Sattari (2013) revealed that organizational culture conditions positively affect organizational trust. The findings of this study are consistent with Ahmad et al. (2011), Jafaei (2011), and Matin (2009). There is a relationship between organizational culture and its components and organizational trust. Jaben \& Isakovic (2018) show that organizations with a culture type that are more focused on creation and collaboration tend to have a higher level of trust in top management.

Research conducted by Gabriel \& Kpakol (2014) shows that perceived managerial competence is significantly correlated with employee cognitive and affective beliefs. Ghimire (2019) illustrates that many factors, including competence, integrity, and virtue, influence nurse behavior through organizational trust in management.

According to Setiawan et al. (2019), the organizational structure provides flexibility for the organization members to work according to their expertise. On the other hand, the delegation of authority and duties to members of the organization at certain organizational structure positions shows its members' trust. Kolaric \& Radojeic's (2011) show that trust and cooperation among employees are not very high. Meanwhile, Latifi \& Shooshtarian (2014) shows a significant relationship between organizational structure and trust dimensions. The organization can meet objectives, adapt to dynamic environments, and survive in the future.

Based on the empirical studies, it can be concluded that the influence of transformational leadership, transactional leadership, organizational culture, managerial competence, and organizational structure on organizational trust. Therefore, there are research gaps related to organizational trust that could be researched at BAPAREKRAF.

Previous empirical research has suggested that leaders' organizational trust mediates the relationship between transformational and transactional leadership and organizational performance. Public leaders need to continue to develop their leadership skills, especially their transformational leadership, as well as build trust to improve performance in their organizations (Asencio, 2016, Ugwu, Enwereuzor, \& Orji, 2015). Employees' trust in leaders mediates the relationship between transformational and transactional leadership and organizational performance. (Asencio, 2016; Ugwu, Enwereuzor \& Orji, 2015). When leaders consistently value, punish, and monitor performance, high or low performers will develop trust in their leaders. Empirical evidence suggests that leaders who engage in transactional leadership behaviors tend to be more trusted among followers (Bradberry \& Tatum, 2002; Greenberg \& Baron, 2003; Pillai, Schriesheim \& Williams, 1999; Podsakoff et al., 1990). In turn, employees who trust their leader will perform at a higher level because they have confidence that their leader will continue to honor their contract over time (Avolio, Bass, \& Jung, 1999).

Kamaamia (2017) states that organizational culture is considered unique for each organization and can improve performance. Research Fard, Babelan \& Sattari (2013) revealed that the conditions of organizational culture and organizational trust are favorable for the company organization, and there is a relationship between organizational culture and the components of organizational trust. Based on this, it is expected that organizational culture has an indirect effect on organizational performance 
through organizational trust.

Managerial competence is defined as a specific type of individual competence, namely, activities, knowledge, skills, attitudes, and personal characteristics needed to improve management performance (Martina et al., 2012). Nowadays, when measuring organizational performance, the better results are more and more referred to not as the organization's material resources, but for its human resources and competencies; competency development has become one of the organization's top priorities (Veliu \& Manxhari, 2017).

The results of previous studies have provided empirical evidence to support the effect of structure on organizational performance. The results show that structure determines performance and that without a suitable structure, an organization is bound to fail (Nwonu, Agbaeze \& Obi-Anike, 2017).

The delegation of authority and duties to members of the organization in certain organizational structure positions shows its members' trust (Setiawan et al., 2019). The significant relationship between organizational structure and trust dimensions will help organizations meet goals, adapt to dynamic environments, and survive in the future.

According to the results of previous research that have been described, it can be formulated the influence of transformational leadership, transactional leadership, organizational culture, managerial competence, and organizational structure on organizational performance. Therefore, a research gap regarding organizational trust as a mediator of organizational performance can be researched at BAPAREKRAF.

\section{METHODS}

The main data used in this study are primary data. This study's respondent is whole Civil servants and Civil Servant Candidates in BAPAREKRAF, in 194 respondents. A questionnaire with a Likert scale instrument five is used to collect the data.

This research uses inferential statistical analysis in the form of a causality analysis of SEM (Structural Equation Modeling) based on component or variance (known as Partial Least Square (PLS)). Figure 1 shows a preliminary research model

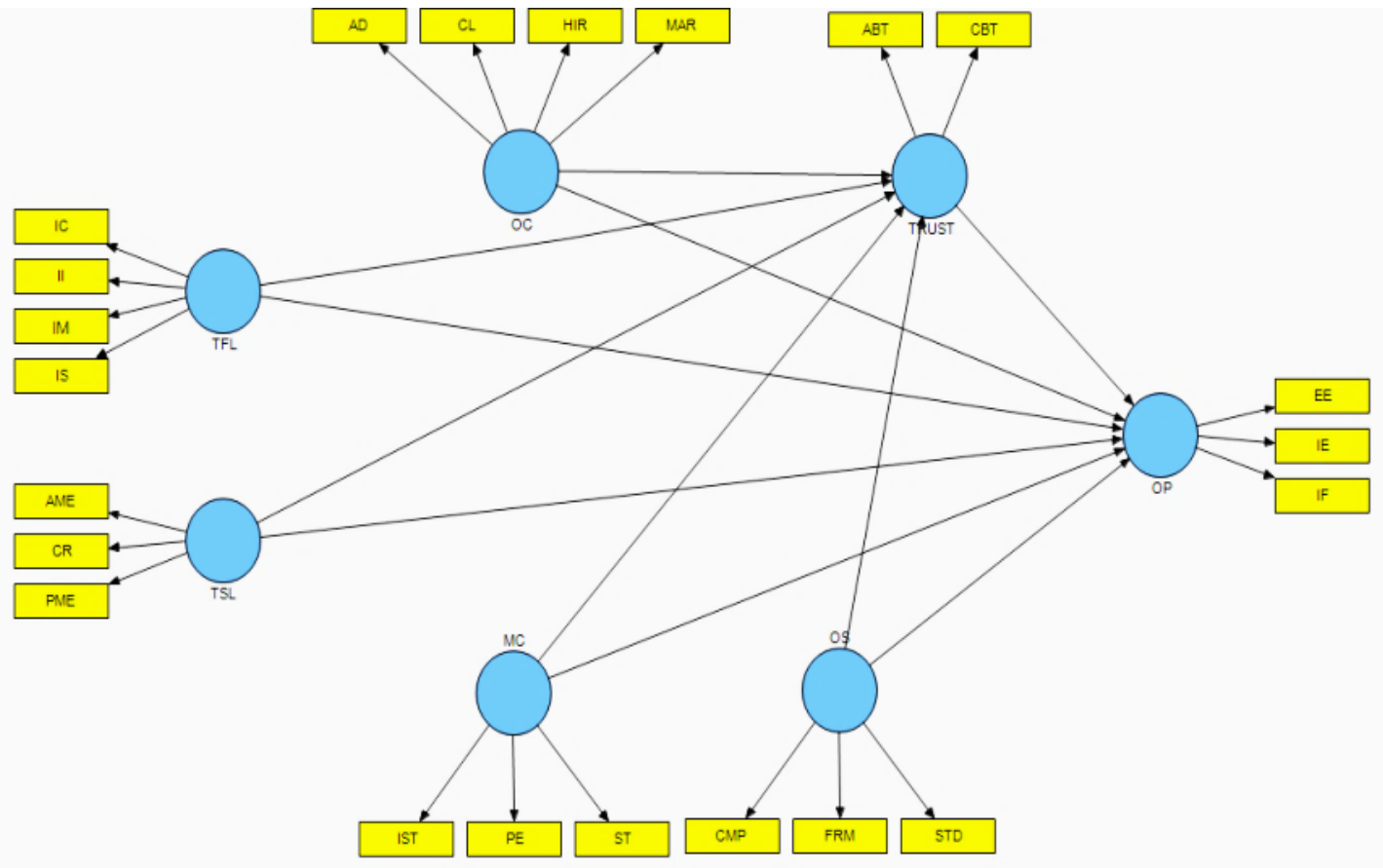

Figure 1. Initial research model 
Table 1. Operational research variables

\begin{tabular}{|c|c|c|c|}
\hline Variable & Definition & Indicator & $\begin{array}{l}\text { Measurement } \\
\text { Scale }\end{array}$ \\
\hline $\begin{array}{l}\text { Transformational } \\
\text { Leadership (TFL) }\end{array}$ & $\begin{array}{l}\text { A leadership style that creates an } \\
\text { environment, so employees are } \\
\text { motivated and energized in a } \\
\text { climate that supports providing } \\
\text { more effective customer service, } \\
\text { strengthening organizational } \\
\text { performance and leading to } \\
\text { financial benefits for shareholders } \\
\text { ((De Jong \& Bruch, (2013), Giroux } \\
\& \text { McLarney, ( 2014). }\end{array}$ & $\begin{array}{ll}\text { 1. } & \text { Idealized Influence } \\
\text { 2. Inspirational } \\
\text { Motivation } \\
\text { 3. Intellectual Stimulation } \\
\text { 4. Individualized } \\
\text { Consideration }\end{array}$ & Ordinal \\
\hline $\begin{array}{l}\text { Transactional } \\
\text { Leadership (TSL) }\end{array}$ & $\begin{array}{l}\text { A leadership style so the leader } \\
\text { encourages the obedience of his } \\
\text { subordinates through reward and } \\
\text { punishment. (Khalil, Iqbal \& Khan, } \\
\text { 2016) }\end{array}$ & $\begin{array}{l}\text { 1. contingent reward, } \\
\text { 2. active management by } \\
\text { exception } \\
\text { 3. passive management by } \\
\text { exception }\end{array}$ & Ordinal \\
\hline $\begin{array}{l}\text { Organizational } \\
\text { Culture (OC) }\end{array}$ & $\begin{array}{l}\text { Culture is "the typical way of } \\
\text { behavior and beliefs that a group of } \\
\text { people has that develops over time } \\
\text { and shares together" (Tarique et al., } \\
2016, \text { p. 124). Organizational } \\
\text { culture is a concrete manifestation } \\
\text { of the shared values and beliefs that } \\
\text { influence it employee behavior (De } \\
\text { Chernatony and Cottam, 2008; } \\
\text { Hoque et al., 2013) }\end{array}$ & $\begin{array}{l}\text { 1. Clan } \\
\text { 2. Adhocracy } \\
\text { 3. Market } \\
\text { 4. Hierarchical }\end{array}$ & Ordinal \\
\hline $\begin{array}{l}\text { Managerial } \\
\text { Competence } \\
\text { (MC) }\end{array}$ & $\begin{array}{l}\text { Managerial competence is the } \\
\text { skills, knowledge and attributes } \\
\text { needed to perform managerial tasks } \\
\text { effectively and efficiently with } \\
\text { readiness and agility for all } \\
\text { professions (Farah and Mwiti, } \\
2017 \text { ) }\end{array}$ & $\begin{array}{ll}\text { 1. } & \text { Strategic } \\
\text { 2. } & \text { Intra-strategic } \\
\text { 3. } & \text { Personal effectiveness }\end{array}$ & Ordinal \\
\hline $\begin{array}{l}\text { Organizational } \\
\text { Structure (OS) }\end{array}$ & $\begin{array}{l}\text { Is a system that determines how } \\
\text { tasks are formally, structured and } \\
\text { coordinated in a group that is } \\
\text { deliberately organized to achieve } \\
\text { common goals (Robbins et al., } \\
\text { 2014; McNamera, 2018) }\end{array}$ & $\begin{array}{ll}\text { 1. } & \text { Complexity } \\
\text { 2. } & \text { Formality } \\
\text { 3. } & \text { Standardization }\end{array}$ & Ordinal \\
\hline $\begin{array}{l}\text { Organizational } \\
\text { Performance } \\
\text { (OP) }\end{array}$ & $\begin{array}{l}\text { The organizational performance } \\
\text { consists of the actual output or } \\
\text { organizational results that are } \\
\text { measured against the intended } \\
\text { output (Richard et al. 2009). } \\
\text { Performance must be achieved } \\
\text { through items such as evaluation, } \\
\text { testing, efficiency, effectiveness } \\
\text { and quality (Bartoli \& Blatrix, } \\
\text { 2015) }\end{array}$ & $\begin{array}{ll}\text { 1. } & \text { Internal Effectiveness } \\
\text { 2. External Effectiveness } \\
\text { 3. Internal Fairness }\end{array}$ & Ordinal \\
\hline $\begin{array}{l}\text { Organizational } \\
\text { Trust (OT) }\end{array}$ & $\begin{array}{l}\text { Organizational trust is about the } \\
\text { positive expectations of individuals } \\
\text { from supervisors, colleagues and } \\
\text { the organization himself to be } \\
\text { honest about promises, decisions } \\
\text { and behavior and not to take } \\
\text { pragmatic actions (Fatma Ince, } \\
2018 \text { ) }\end{array}$ & $\begin{array}{l}\text { 1. Cognition-based trust } \\
\text { 2. Affect-based trust }\end{array}$ & Ordinal \\
\hline
\end{tabular}




\section{RESULTS AND DISCUSSION}

In general, BAPAREKRAF's organizational performance is relatively good. It is indicated by the average value of the OP variable of 4.23 (Likert scale 1 - 5) (see Table 2). Other variables in this study are also categorized as good, except for the OC (organization culture) variable, which is categorized as neutral.

Table 2. Description of research variables

\begin{tabular}{lc}
\hline Variable & Average value \\
\hline Transformational Leadership (TFL) & 4.54381 \\
Transactional Leadership (TSL) & 4.14089 \\
Organization Culture (OC) & 3.91366 \\
Managerial Competency (MC) & 4.09278 \\
Organizational Structure (OS) & 4.22680 \\
Trust (Trust) & 4.04124 \\
Organizational Performance (OP) & 4.13660 \\
\hline
\end{tabular}

Before conducting further analysis, first, an evaluation of the initial model is related to the indicators' validity and reliability in the latent variables (constructs). The validity test used the convergent test and discriminant validity of the indicators. The reliability test uses two criteria, namely composite reliability and Cronbachs alpha.

The construct reliability test was measured by two criteria, namely composite reliability and Cronbachs alpha. Both Alpha Cronbach and Composite Reliability must be above 0.7. For Alpha Cronbach, up to 0.6 is still allowed.

Based on the initial model test (validity and reliability), there are two indicators of TSL (AME and PME), three OC indicators (CL, HIR, and MAR), one MC indicator (PE), and one OS indicator (CMP) which are invalid and unreliable. The seven indicators were excluded from the model. In other words, all indicators in the model are valid and reliable. The modified model is given in Figure 2.

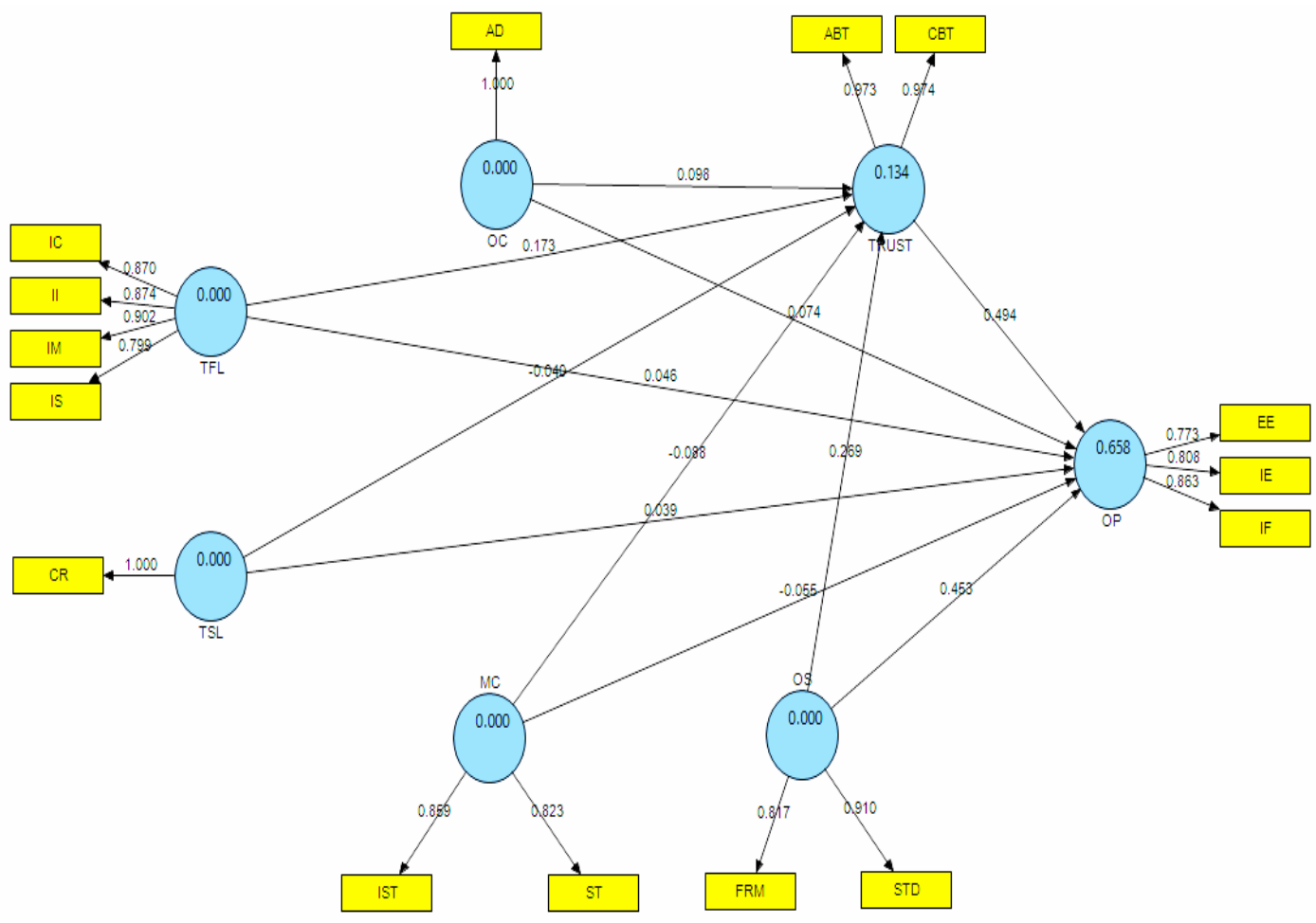

Figure 2. Results (modified) of the second model 
Convergent validity from testing the indicator (measurement model) can be seen from the loading factor's value. However, it can also be seen from the results of the calculation of the second model in the form of Average Variance Extracted and Composite Reliability. The following table is Average Variance Extracted and Composite Reliability:

Table 3. AVE and composite reliability

\begin{tabular}{cccc}
\hline Variable & Average Variance Extracted (AVE) & Composite Reliability & Information \\
\hline MC & 0.707643 & 0.828731 & Valid \\
OC & 1,000000 & 1,000000 & Valid \\
OP & 0.664843 & 0.855882 & Valid \\
OS & 0.747583 & 0.855208 & Valid \\
TFL & 0.742882 & 0.920220 & Valid \\
TRUST & 0.947961 & 0.973285 & Valid \\
TSL & 1,000000 & 1,000000 & Valid \\
\hline
\end{tabular}

Based on the loading factor value, average variance extracted, and composite reliability, each variable's indicators are reliable and valid, reflecting their respective variables. The testing of the structural model's goodness of fit against the inner model using predictive-relevance (Q2) values (Solimun, 2011). Table 4 shows model R Square.

Table 4. Model R Square

\begin{tabular}{cc}
\hline Variable & R Square \\
\hline MC & \\
OC & 0.658287 \\
OP & \\
OS & \\
TFL & 0.134312 \\
TRUST & \\
TSL & \\
\hline
\end{tabular}

The result of predictive-relevance value calculation Is 0.443564 or $44.35 \%$, which shows that the diversity of data explained by the model is $44.35 \%$. These results indicate that the value of Q Square> 0 gives the meaning that this research model has predictiverelevance and can be used for hypothesis testing.

Table 5. Total effects (Mean, STDEV, T-values)

\begin{tabular}{|c|c|c|c|c|c|}
\hline & $\begin{array}{c}\text { Original } \\
\text { sample } \\
\text { estimate }(\mathrm{O})\end{array}$ & $\begin{array}{l}\text { Sample Mean } \\
\text { (M) }\end{array}$ & $\begin{array}{l}\text { Standard } \\
\text { Deviation } \\
\text { (STDEV) }\end{array}$ & $\begin{array}{c}\text { Standard } \\
\text { Error } \\
\text { (STERR) }\end{array}$ & $\begin{array}{l}\text { T Statistics } \\
(|\mathrm{O} / \mathrm{STERR}|)\end{array}$ \\
\hline MC -> OP & -0.098682 & -0.101475 & 0.032930 & 0.032930 & 2.996666 \\
\hline MC -> TRUST & -0.088227 & -0.091025 & 0.047723 & 0.047723 & 1.848739 \\
\hline $\mathrm{OC}->\mathrm{OP}$ & 0.122499 & 0.120460 & 0.031320 & 0.031320 & 3.911169 \\
\hline OC -> TRUST & 0.097734 & 0.096208 & 0.035907 & 0.035907 & 2.721837 \\
\hline OS -> OP & 0.585852 & 0.584588 & 0.032560 & 0.032560 & 17.993154 \\
\hline OS $->$ TRUST & 0.268648 & 0.270063 & 0.044016 & 0.044016 & 6.103428 \\
\hline TFL -> OP & 0.131864 & 0.139148 & 0.050064 & 0.050064 & 2.633934 \\
\hline TFL -> TRUST & 0.172972 & 0.180558 & 0.069030 & 0.069030 & 2.505749 \\
\hline TRUST $->$ OP & 0.494162 & 0.494320 & 0.029838 & 0.029838 & 16.561705 \\
\hline TSL -> OP & 0.019050 & 0.018723 & 0.053132 & 0.053132 & 0.358531 \\
\hline TSL -> TRUST & -0.040377 & -0.040246 & 0.070653 & 0.070653 & 0.571480 \\
\hline
\end{tabular}


Transformational leadership reflected by idealized influence, inspirational motivation, intellectual stimulation, and individual consideration positively and significantly impact organizational performance reflected by internal effectiveness, external effectiveness, and internal justice. The results of this study support research conducted by Al Khajeh (2018), Asencio (2016), and Toufaili (2017).

Transactional leadership reflected by contingency rewards has no effect on organizational performance reflected by internal effectiveness, external effectiveness, and internal justice. This result is in line with the arguments of Antonakis, Avolio, and Sivasubramaniam (in Bass \& Riggio, 2006). However, it is different from previous research by Ahmad \& Ejaz (2019) and Haq \& Chandio (2017).

Organizational culture reflected by the Adhocracy culture has a positive and significant influence on organizational performance reflected by internal effectiveness, external effectiveness, and internal justice. This study's results support research done previously by Kim \& Chang (2018), Sengottuvel \& Aktharsha (2016), Meng \& Berger. (2019), Joseph \& Kibera (2019)

Managerial competence, reflected by strategic and intra-strategic, has a negative and significant impact on organizational performance reflected by internal effectiveness, external effectiveness, and internal justice. These results contradict previous studies by Veliu \& Manxhari (2017), Suárez, Martelo \& Franco (2018), and Ncube \& Chimucheka (2019).

The organizational structure reflected by formality and standardization has a positive and significant impact on organizational performance reflected by internal effectiveness, external effectiveness, and internal justice. The results of this study support Estalaki (2017) and contrary to the results by Nene \& Pillay (2019)

Organizational trust reflected by cognitive-based trust and influence-based trust positively influences organizational performance reflected by internal effectiveness, external effectiveness, and internal justice. The results of this study support research that has been done previously by Fatma Ince (2018), Guinot \& Chiva (2018), Singh \& Desa (2018), and Botwe, Kenneth \& Masih (2016).

Transformational leadership reflected by idealized influence, inspirational motivation, intellectual stimulation, and individual consideration positively and significantly impact employee trust reflected by cognitive-based trust and influencebased belief. The results of this study support research that has been done previously by Yue et al. (2019), Yasir et al. (2016), and Uslu \& Oklay (2015).

Transactional leadership reflected by contingent rewards has no effect on employee trust reflected by cognitive-based trust and influence-based trust. This study's results contradict research that has been done previously by Yasir et al. (2016) and Mehmood (2016).

Organizational culture reflected by the Adhocracy culture has a positive and significant influence on employee trust reflected by cognitive-based trust and influencebased belief. This study's results support research done previously by Fard, Babelan \& Sattari (2013) and Jabeen \& Isakovic_(2018).

Managerial competence reflected by strategic and intra-strategic does not affect employee trust reflected by cognitive-based trust and influence-based trust. This study's results contradict research done previously by Gabriel \& Kpakol (2014) and Ghimire (2019).

The organizational structure reflected by formality and standardization positively influences organizational trust reflected by cognitive-based trust and influence-based 
trust.

This study's results support research that has been done previously by Latifi \& Shooshtarian (2014) and Kolaric \& Radojeic (2011) stated that organizational structure is positively and significantly related to employee organizational trust.

Table 6. Recapitulation of organizational trust mediation tests

\begin{tabular}{lcccc}
\hline \multicolumn{1}{c}{ Variable } & $\mathrm{t}$-count & $\mathrm{t}$-table & $\mathrm{p}$-value & Information \\
\hline Transformational leadership (TFL) & 5,440 & 1.97 & 0.00 & Accepted \\
Transactional leadership (TSL) & 2,841 & 1.97 & 0.00 & Accepted \\
Organizational culture (OC) & 2,087 & 1.97 & 0.03 & Accepted \\
Managerial competence (MC) & $-2,238$ & 1.97 & 0.02 & Rejected \\
Organizational structure (OS) & 7,436 & 1.97 & 0.00 & Accepted \\
\hline
\end{tabular}

It can be concluded that transformational leadership, transactional leadership, organizational culture, organizational structure have a positive and significant influence on organizational performance mediated by organizational trust. On the other hand, managerial competence does not affect organizational performance mediated by an employee trust.

Organizational trust can mediate the effect of transformational leadership on organizational performance. Leadership at BAPAREKRAF that provides ideal influence, inspirational motivation, intellectual stimulation, and individual considerations creates trust in employees to increase competence, ability, integrity, and a sense of dependence on the organization to increase organizational performance.

This study's results further strengthen and support previous empirical research that has suggested that employees' trust in leaders mediates the relationship between transformational and transactional leadership and organizational performance. (Asencio, 2016; Ugwu, Enwereuzor, \& Orji, 2015).

Organizational trust can mediate the effect of transactional leadership on organizational performance. The leadership's reward policy in the form of material can provide trust in competence, ability, and integrity to create a dependency from employees to make organizational performance better.

This study's results further strengthen and support previous empirical research that has suggested that employees' trust in leaders mediates the relationship between transformational and transactional leadership and organizational performance. (Asencio, 2016; Ugwu, Enwereuzor, \& Orji, 2015).

Organizational trust can mediate organizational culture on organizational performance. The existence of an innovative and creative culture at BAPAREKRAF can increase employees' competence, ability, and integrity at work, make employees feel dependent and comfortable with their organization, and ultimately improve organizational performance.

This study's results further strengthen and support the previous empirical research that states that organizational culture is considered unique for each organization and can improve performance. (Kamaamia, 2017). It also strengthens the result researched by Fard, Babelan \& Sattari (2013), which revealed that organizational culture and organizational trust are favorable for the company organization. There is a relationship between organizational culture and the components of organizational trust.

Organizational trust can mediate an organizational structure on organizational performance. It shows that a formal and standardized organizational structure provides confidence for employees to improve competence, ability, integrity, and a sense of belonging to the organization, thus leading to increased external and internal performance 
of the organization.

These results further strengthen and support previous empirical research that stated that employees' trust in leaders mediates the relationship between organizational structure (OS) and organizational performance. The significant relationship between organizational structure and dimensions of trust will help organizations meet goals, adapt to dynamic environments, and survive in the future (Nwonu, Agbaeze \& Obi-Anike, 2017; Setiawan et al., 2019)

Otherwise, organizational trust is not able to mediate managerial competence in organizational performance. Strategic and intra-strategic implementation obstructed employee freedom in increasing competence, ability, integrity, and a sense of dependence on the organization. As a result, it does not improve organizational performance. This study's results do not support previous empirical research states that employees' trust in leaders mediates the relationship between managerial competence and organizational performance (Veliu and Manxhari, 2017).

\section{CONCLUSIONS AND RECOMMENDATIONS}

\section{Conclusion}

Transformational leadership, organizational culture, managerial competence, organizational structure, organizational trust affect organizational performance, but transactional leadership does not affect organizational performance. It shows that leaders at the managerial level in providing contingent rewards to employees in material form do not affect BAPAREKRAF.

Besides that, transformational leadership, organizational culture, organizational structure affect organizational trust, but transactional leadership and managerial competence do not affect organizational trust. It shows that the reward in the form of material cannot increase the competence, ability, and integrity of employees at work and dependence on BAPAREKRAF.

Furthermore, transformational leadership, transactional leadership, organizational culture, and organizational structure can be mediated by organizational performance beliefs. However, organizational beliefs cannot mediate managerial abilities in the form of Strategic and Intra-Strategic in cognitive-based and affective based on BAPAREKRAF's performance in realizing Internal Effectiveness, Effectiveness External, and Internal Justice.

\section{Recommendation}

The managers at BAPAREKRAF should not give rewards in the form of materials to improve the performance of BAPAREKRAF. Besides, managers should also appreciate motivation, praise, and opportunities and increase their strategic and intrastrategic abilities to increase organizational trust.

Recommendations for further research are to be able to examine the managerial competency qualifications required by BAPAREKRAF.

\section{REFERENCES}

Ahmad, M., \& Ejaz, T., (2019), Transactional and Transformational leadership impact on Organizational Performance: Evidence from Textile sector of Pakistan. European Online Journal of Natural and Social Sciences: Proceedings, 8(2 (s)), 97-103

Al Khajeh. E. H., (2018), Impact of Leadership Styles on Organizational Performance, Lincoln University College, UAE 
Antonakis, A. \& Sivasubramaniam. (2003). Context and leadership: An examination of the nine-factor full range leadership theory using the Multifactor Leadership Questionnaire. The Leadership Quarterly, 14, 261-295

Arif, S. \& Akram, A. (2018). Transformational Leadership and Organizational Performance, The Mediating Role of Organizational Innovation, SEISENSE Journal of Management, 1(3), 59 - 75

Asencio, H. (2016). Leadership, Trust And Organizational Performance In The Public Sector, Transylvanian Review of Administrative Sciences, Special Issue 2016, 5-22

Avolio, B.J., Bass, B.M. \& Jung. (1999). Re-examining the components of transformational and transactional leadership using the Multifactor Leadership Questionnaire. Journal of Occupational and Organizational Psychology, 72(4), 441-462. https://doi.org/10.1348/096317999166789

Bartoli, A. \& Blatrix, C. (2015) Management dans les organizations publiques - 4ème édition. Dunod, Paris.

Bass, B.M. \& Riggio, R.E. (2006). Transformational Leadership Second Edition. New Jersey: Lawrence Erlbaum Associates, Publishers

Bass, B.M. (1999). Two decades of research and development in transformational leadership. European Journal of Work and Organizational Psychology, 8(1), 9-32. https://doi.org/10.1080/135943299398410.

Toufaili, B.E. (2017). The Effects Of Transformational Leadership On Organizational Performance - A Theoretical Approach. Proceedings of The International Management Conference, Faculty Of Management, Academy Of Economic Studies, Bucharest, Romania.

Botwe, P.B., Kenneth, A.B., \& Masih, E. (2016). Concept of Trust and Its Effect on Performance in an Organisation, The International Journal Of Business \& Management, 4(2), 123 - 128

Bradberry, T. \& Tatum, B.C. (2002). Seeking justice in organizations: The time is now. Proceeding of the 2nd Symposium Biannual International Conference on Personal Meaning on Freedom, Responsibility, Justice, July 18-21, Vancouver, BC. 174

De Jong, S. \& Bruch, H. (2013). The importance of a homogeneous transformational leadership climate for organizational performance, International Journal of Leadership Studies, 8(1), 61 - 78

Estalaki, K. G. (2017). On the impact of organizational structure on organizational efficiency in industrial units: industrial units of Kerman and Hormozgan Provinces. $\begin{array}{llll}\text { Estacao Cientfika } & \text { (UNIFAP), } & \text { 95-105. }\end{array}$ https://doi.org/10.18468/estcien.2017v7n3.p95-105

Farah, M.B. \& Evans, M. (2017). Analysis of Managerial Competencies And Their Influence On Staff Productivity: A Case Of Wajir County Government Employees, Human Resource and Leadership Journal, 2(2), 81 - 107

Fard, A.M., Babelan, A.Z., \& Sattari, S. (2013). The Relation between Organizational Culture and Organizational Trust in Customs Headquarters of Iran, International Research Journal of Applied and Basic Sciences 4(1),164-167

Fatma, I. (2018). The effects of organizational trust on organizational toxicity and performance, International Journal of Academic Research in Business and Social Sciences, 8(11), 67315-67318

Gabriel, G., Odinioha, J.M., Kpakol, K. \& Gbaraka, A. (2014). Mediating Role of Power Distance on the Association of Perceived Managerial Competency and Employee Trust in the Nigerian Manufacturing Industry, International Journal of Managerial 
Studies and Research (IJMSR), 2(10), 1-12

Ghimire, B. (2019). Factors Affecting Employees' Trust in Management. NCC Journal, 4(1), 31-39. https://doi.org/10.3126/nccj.v4i1.24732

Ghozali, I. (2008). Aplikasi Analisis Multivariate dengan Program SPSS. Semarang: Badan Penerbit Universitas Diponegoro

Giroux, T. \& McLarney, C. (2014). Exploring the leadership continuum: The relevance of transformational leadership on organizational performance. Proceedings of the Northeast Region Decision Sciences Institute, 43(4), 862-886.

Greenberg, J. \& Baron, R.A. (2003). Behaviour in Organization. Understanding and managing the human side of work. Canada: Prentice Hall.

Guinot, J. \& Chiva, R. (2018). Vertical Trust Within Organizations and Performance: A Systematic Review, Human Resource Development Review, 0(00), 1-32

Haq, S. \& Chandio, J.A. (2017). Transactional Leadership and its Organizational Performance: A Critical Analysis, International Journal of Trend in Scientific Research and Development (IJTSRD), 2(1), 135 - 139

Hardiani, H., Hastuti, D., \& Junaidi, J. (2019). An Analysis of The Attitudinal, Contextual and Gender Perspectives of The Entrepreneurial Intentions Among Indonesian Millennials. Malaysian Management Journal, 23, 135-150

Hoque, Z., Covaleski, M. Gooneratne, T.N. (2013). Theoretical Triangulation and Pluralism In Research Methods In Organisational And Accounting Research, Accounting, Auditing And Accountability Journal, 26(7), 1170-1198.

Jabeen, F. \& Isakovic, A.A. (2018). Examining the impact of organizational culture on trust and career satisfaction in the UAE public sector: A competing values perspective, Employee Relations, 40(6), 1036-1053. https://doi.org/10.1108/ER02-2017-0038

Jafaei, M. (2011). Evaluation of stability criteria of regions in Iran and the world to achieve urban sustainable development. - Conference on Sustainable Architecture and Urban Development, Hamedan-Iran, Sama vocational schools.

Joseph, O.O \& Kibera, F. (2019). Organizational Culture and Performance: Evidence From Microfinance Institutions in Kenya. SAGE Open, January-March 2019: 111, DOI:10.1177/2158244019835934, journals.sagepub.com/home/sgo

Junaidi, J. (2017). Kualitas sumberdaya manusia dan sifat kewirausahaan pelaku industri kreatif usaha mikro kecil dan menengah di Kota Jambi. Jurnal Paradigma Ekonomika, 12(2), 101-112.

Kamaamia, A.T. (2017). The Effect Of Organizational Culture On Organizational Performance: A Case Of Kenya School Of Monetary Studies, [Master' Thesis] United States International University - Africa

Khalil, U., Iqbal, J. \& Khan, A. (2016). Exploring Leadership Styles of School Administrators in Pakistan. FWU Journal of Social Sciences, 10(1), 39-47.

Kim, T. \& Chang, J. (2018). Organizational culture and performance: a macro-level, longitudinal study, Leadership \& Organization Development Journal, 40(1), DOI 10.1108/LODJ-08-2018-0291

Kolaric, B. \& Radojčić, S. (2011). Organizational Structure Influence on the Level of Trust among Employees: The Case Study of "Telecom Serbia", International Journal of Business Administration, 2(1), 28 - 37 doi:10.5430/ijba.v2n1p28

Latifi M. \& Shooshtarian, Z. (2014). The Effects Of Organizational Structure On Organizational Trust And Effectiveness, Polish Journal Of Management Studies, 10(2), $73-84$ 
Long, R. \& Singh, P. (2009). Strategic Compensation in Canada. Nelson Education Limited

Martina, K., Hana, U. \& Jiř́, F. (2012). Identification of managerial competencies in knowledge-based organizations. Journal of Competitiveness, 4(1), 129-142.

Matin, Z. (2009). The role of university in creating affecting factors on happiness, Culture in Islamic University Journal, 2, 4 - 27.

Mc Namera, (2018). Definition of organization. Available from https://managementhelp.org/organizations/definition.htm

Mehmood, A. (2016). Transactional Leadership Style and Its Effect On Organizational Commitment: Employee Trust As A Mediator Anum Mehmood, Pakistan, Sci.Int. 28(5), 57-64

Meng, J. \& Berger, B.K. (2019). The impact of organizational culture and leadership performance on PR professionals' job satisfaction: Testing the joint mediating effects of engagement and trust, Public Relations Review, 45 (2019) 64-75

Ncube, M.S. \& Chimucheka, T. (2019). The effect of managerial competencies on the performance of small and medium enterprises in Makana Municipality, South Africa, African Journal of Hospitality, Tourism and Leisure, 8(5), 1 - 15

Nene, S.W. \& Pillay, A.S. (2019). An Investigation of The Impact of Organisational Structure on Organisational Performance, Financial Risk and Management Reviews, 5(1), 10-24

Nwonu, C.O., Agbaeze, E.K. \& Obi-Anike, H.O. (2017). Effect of Organizational Structure on Performance of Selected Manufacturing Companies in Enugu State Nigeria.The International Journal Of Business \& Management, 5(5), 190-206

Pillai, R., Schriesheim, C.A. \& Williams, E.S. (1999). Fairness perceptions and trust as mediators for transformational and transactional leadership: A two-sample study. Journal of Management, $25(6), \quad$ 897933. https://doi.org/10.1177/014920639902500606

Podsakoff, P.M., MacKenzie, S.B., Moorman, R.H., \& Fetter, R. (1990). Transformational Leader Behaviors and Their Effects On Followers' Trust In Leader, Satisfaction, And Organizational Citizenship Behaviors, The Leadership Quarterly, 1(2),107-142

Richard, P.J., Devinney, T.M., Yip, G.S. \& Johnson, G. (2009). Measuring Organizational Performance: Towards Methodological Best Practice. Journal of Management, 35(3), 718-804.

Robbins, S.P., De Cenzo, D. \& Coulter, M. (2014). Fundamentals of management: Management Myths Debunked. London: Pearsons Higher Ed.

Ahmad, S., Hasan, J., Rahim, K., Mohsen, P., Ramin, M. \& Bahman, A.N. (2011). A Case Study: The Association Between Organizational Culture With Management Knowledge In Hasheminezhad Hospital - Tehran, Hospital, 10 (2), 37

Sengottuvel, A. Aktharsha, U.S. (2016). The Influence of Organizational Culture on Organizational Performance in Information Technology Sector ,IOSR Journal of Business and Management (IOSR-JBM), 18(10), 56-64

Singh, K. \& Desa, Z.M. (2018). Organizational Trust and Job Performance: A Study Of Land and Survey Department, International Journal of Academic Research in Business and Social Sciences, 8(11), 1954 - 1961

Solimun \& Rinaldo. (2009). Metode Statistika Multivariat Pemodelan Persamaan Struktural (SEM) Pendekatan WarpPLS, Malang: Universitas Brawijaya Press

Suárez, M. Martelo, R.J. \& Franco, D. (2018). Influence of Managerial Competencies in 
the Organizational Culture of Public University Institutes, Contemporary Engineering Sciences, 11(32), 1579-1589 https://doi.org/10.12988/ces.2018.84156 Tarique, I., Briscoe, D.R., \& Schuler, R.S. (2016). International Human Resource Management: Policies and Practices for Multinational Enterprises (Global HRM) 5th Edition. Amazon Books Club

Ugwu, L.I., Enwereuzor, I.K. \& Orji, E.U. (2016). Is trust in leadership a mediator between transformational leadership and in-role performance among small-scale factory workers?. Rev Manag Sci 10, 629-648 https://doi.org/10.1007/s11846-0150170-Z

Uslu, F. \& Oklay, E. (2015). The Effect of Leadership on Organizational Trust, Leadership and Organizational Outcomes, Meta-Analysis of Empirical Studies, London: Springer International Publishing Switzerland.

Veliu, L. \& Manxhari, M. (2017). The Impact Of Managerial Competencies On Business, Performance: SME's In Kosovo, Journal of Management, 30(1), 59-65.

Yasir, M., Imran, R. Irshan, M.K., Mohamad, N.A., \& Khan, M.M. (2016). Leadership Styles in Relation to Employees' Trust and Organizational Change Capacity: Evidence From Non-Profit Organizations, SAGE Open, October-December 2016: 1-12 DOI: $10.1177 / 2158244016675396$

Yue, C.A., Men, L.R. \& Ferguson, M.A. (2019). Bridging transformational leadership, transparent communication, and employee openness to change: The mediating role of trust, Public Relations Review, 45 (2019) 101779 